\title{
PENGARUH PARTISIPASI MASYARAKAT, KOMPETENSI SUMBER DAYA MANUSIA, DAN PENGAWASAN TERHADAP AKUNTABILITAS PENGELOLAAN DANA DESA (STUDI KASUS PADA KABUPATEN ACEH BARAT DAYA)
}

\author{
Siti Umaira*1, Adnan ${ }^{* 2}$ \\ ${ }^{1,2}$ Program Studi Akuntansi Fakultas Ekonomi dan Bisnis Universitas Syiah Kuala \\ e-mail: siti.umairaarfat@gmail.com ${ }^{* 1}$, adnan_bensaadi@ unsyiah.ac.id ${ }^{* 2}$
}

\begin{abstract}
The purpose of this study is to examine the effects of community participation, human resource competence, and supervision on accountability of village fund management (a case study in Kabupaten Aceh Barat Daya). This is a quantitative study with questionnaire used as the primary data elicitation and Likert scale as the measure. The study was carried out in Kabupaten Aceh Barat Daya. A total of 120 respondents were selected, consisting of the villages' tuha peut and public figures. The simple random sampling was used as the sampling technique with the Slovin formula for determining the number of samples. The multiple linear regression was employed as the data analysis technique, facilitated by the SPSS version 21. The results indicate that the public participation (X1), human resource competency (X2), and supervision (X3) variables either partially or simultaneously have significant effects on the accountability of village fund management $(Y)$.
\end{abstract}

Keywords: Accountability of Village Fund Management, Community Participation, Human Resource Competence, Supervision

\section{Pendahuluan}

Penyerahan wewenang oleh pemerintahan pusat kepada daerah otonom berdasarkan Asas Otonomi disebut desentralisasi (Undang-Undang Nomor 23 Tahun 2014). Tujuan desentralisasi ialah meningkatkan efisiensi dan efektivitas serta fungsi pelayanan pemerintahan pada semua lapisan masyarakat (Nadir, 2013). Artinya pemerintah daerah bisa menyusun, mengatur serta mengurus daerahnya tanpa bergantung pada pemerintah pusat. Dengan adanya desentralisasi akan memberi peluang kepada pemerintah daerah untuk mengatur wilayahnya sendiri berdasarkan wewenang dan tanggungjawab yang telah diberikan dan akan berdampak terhadap pembangunan daerah tertinggal seperti aceh, sehingga bisa mandiri dan dapat memajukan daerahnya.

Salah satu bentuk desentraliasasi ialah digulirkannya dana desa pada tahun 2015. Dalam rangka terwujudnya desentralisasi dari pemerintah pusat ke pemerintah daerah, dimana wewenang dalam mengelola keuangan telah dilimpahkan ke desa agar mengalokasikan dana yang telah diberikan untuk meningkatkan pembangunan dan kesejahteraan masyarakat. Tujuannya untuk melindungi dan membentuk pemerintah desa yang berkompeten, efisien, efektif, terbuka dan bertanggungjawab dalam mewujudkan kesejahteraan masyarakatnya, memberi kemajuan ekonomi masyarkat, dan menghindari kesenjangan pembangunan nasional.

Berdasarkan Badan Pusat Statistik (BPS) 2018, desa yang tersebar diseluruh indonesia berjumlah 83.344 desa. Seluruh desa di Indonesia merupakan bagian yang paling kecil, yang dinaungi oleh kabupaten di Indonesia. Tiap desa dipimpin oleh kepala desa beserta perangkatnya. Kepala desa bertugas untuk melaksanakan pemerintahan desa, meningkatkan pembangunan desa, membina masyarakat desa, serta memberdayakan masyarakat desa. Untuk menjalankan tugasnya, setiap desa memiliki wewenang untuk memegang kekuasaan dalam mengelola aset atau keuangan desa, serta menetapkan APBDes (Anggaran Pendapatan dan Belanja Desa) (Undang-Undang No.6 tahun 2014).

Jumlah dana desa mengalami peningkatan secara signifikan setiap tahunnya seperti disajikan dalam tabel 1.1 yang memperlihatkan jumlah dana yang diterima setiap desa sejak tahun 2015 sampai dengan tahun 2018. 
Tabel 1.1

Alokasi Dana Desa Tahun 2015 s/d 2018

\begin{tabular}{|l|l|l|l|}
\hline No & Tahun & $\begin{array}{l}\text { Jumlah } \\
\text { seluruh dana } \\
\text { desa }\end{array}$ & $\begin{array}{l}\text { Jumlah dana } \\
\text { per desa }\end{array}$ \\
\hline 1 & 2015 & Rp20,7 Triliun & Rp280 Juta \\
\hline 2 & 2016 & Rp46,98 Triliun & Rp628 Juta \\
\hline 3 & 2017 & Rp60 Triliun & Rp800 Juta \\
\hline 4 & 2018 & Rp60 Triliun & Rp800 Juta \\
\hline
\end{tabular}

Sumber : Provinsi Aceh Dalam Angka 2015, 2016, 2017, 2018

Besarnya jumlah dana yang ditransfer dari APBN (Anggaran Pendapatan dan Belanja Negara) menimbulkan kekhawatiran berbagai pihak karena rawan terjadi korupsi dan pengelolaan yang tidak efisien dan efektif, semakin tinggi dana yang diberikan maka akan semakin tinggi tingkat kerugian negara yang disebabkan oleh alokasi dana desa tersebut. Berbagai pelanggaran telah terjadi di desa seluruh indonesia. Pelanggaran-pelanggaran tersebut disebabkan faktor integritas dan pengawasan yang lemah. Kemungkinan juga penyebab dari palanggaran tersebut ialah ketidaktahuan aparatur desa terhadap regulasi yang ada, ataupun terdapat unsur kesengajaan dengan lemahnya sistem dan prosedur keuangan menimbulkan niat jahat untuk melakukan kecurangan (Serambi Indonesia, 2017).

Permasalahan yang sering terjadi mengenai akuntabilitas dana gampong ialah minimnya pengetahuan yang dimiliki aparatur gampong. Pengelolaan keuangan desa diperlukan pengetahuan mengenai akuntansi agar mampu dalam menyusun laporan keuangan. Setyoko (2011) menyatakan bahwa perangkat desa yang tidak memiliki pemahaman akuntansi akan mengalami kesulitan dalam menyusun laporan keuangan. Perwujudan pencapaian akuntabilitas salah satunya adalah pelaporan pertanggungjawaban keuangan yang sesuai standar. Kurnia juga menegaskan hal yang sama, ia menuturkan bahwa kegiatan pelaporan keuangan desa sering bermasalah dikarenakan perangkat desa yang belum melek akuntansi (Berita satu, 2015). Mengingat dana yang digulirkan untuk desa cukup besar dan kewenangan diberikan pada perangkat desa yang minim pengetahuan, akan berpotensi melakukan korupsi oleh tenaga pendamping dengan memanfaatkan lemahnya aparat desa (Pramesti, 2015).
Pemerintah daerah memiliki peranan dalam memperhatikan mengenai kapabilitas pengelola keuangan gampong dengan memberikan petunjuk mengenai pengelolaan keuangan secara detail dalam rangka penyelenggaraan, penatausahaan dan pertanggungjawaban pengelolaan keuangan. Perangkat gampong perlu diberikan sosialisasi atau pelatihan untuk meningkatkan pemahaman mengenai pengelolaan keuangan dan pertanggungjawaban dana gampong.

Akuntabilitas menjadi indikator penting dalam mengukur kemampuan suatu pemerintahan untuk memdapatkan kepercayaan masyarakat dan menjadi salah satu parameter dari tinggi atau rendahnya partisipasi masyarakat (Kholmi, 2011). Akuntabilitas penting dalam pengelolaan dana desa untuk memberikan kepastian kepercayaan masyarakat kepada pemerintah serta menjadi penghubung kesenjangan antara pemerintah dengan masyarakat (Aucoin dan Heintzmen, 2000).

Persoalan korupsi pada dana gampong juga diakibatkan karena tidak baiknya perencanaan manajemen dana gampong, jumlah dana gampong yang besar itu harus diberikan pendampingan, pengawasan serta pemeriksaan terus menerus. Secara nyata bisa dilihat bahwa pengelolaan dana gampong kurang bagus, hal itu bisa disebabkan karena kurangnya partisipasi masyarakat dalam menyusun anggaran, rendahnya pengetahuan yang dimiliki aparatur gampong, serta ketidakefektifan pengawasan dalam pengalokasian dana gampong yang merujuk pada lemahnya pertanggungjawaban dalam penggunaan dana gampong tersebut.

Pengelolaan dana gampong pada Kabupaten Aceh Barat Daya telah terjadi beberapa permasalahan seperti keterlambatan penyampaian laporan yang mengakibatkan tidak direalisasikan dana gampong untuk tahun selanjutnya, seperti yang terjadi pada tahun 2018 sebanyak 25 dari 152 gampong di Kabupaten Aceh Barat Daya belum menyerahkan Laporan Pertanggungjawaban (LPj) dana desa tahap pertama sehingga berakibat pada terhambatnya pencairan dana tahap kedua dan juga ketidaksesuaian laporan yang dibuat dengan yang direalisasikan, serta belum optimalnya penyerapan anggaran (Portal Satu, 2018). Hal ini mengakibatkan tidak tercapainya akuntabilitas pengelolaan dana desa. oleh karena itu, dalam rangka penyelenggaraan pemerintahan 
gampong dituntut untuk adanya transparansi, akuntabilitas, dan partisipasi, baik dari aspek keuangan, kinerja, maupun kepatuhan terhadap peraturan perundang-undangan.

Berdasarkan uraian fenomena dan latar belakang yang telah dipaparkan, maka penulis tertarik untuk melakukan penelitian dengan judul "Pengaruh Partisipasi Masyarakat, Kompetensi Sumber Daya Manusia, dan Pengawasan Terhadap Akuntabilitas Pengelolaan Dana Gampong (Studi Kasus Pada Kabupaten Aceh Barat Daya)"

\section{Kerangka Teoritis Dan Pengembangan Hipotesis \\ Pemerintahan Gampong}

Pemerintahan Desa (Gampong) merupakan pelaksanaan urusan pemerintahan \& kepentingan masyarakatnya dalam sistem pemerintahan Negara Kesatuan Republik Indonesia. Pemerintah desa dipimpin oleh kepala desa beserta perangkat desa/gampong yang mana dalam pembinaan kemasyarakatan, pelaksanaan pembangunan, serta pemberdayaan masyarakat desa harus didasarkan pada Pancasila, UUD 1945, dan Bhinneka Tunggal Ika.

\section{Partisipasi Masyarakat}

Partisipasi adalah seseorang dengan sadarnya terlibat berinteraksi sosial dalam situasi tertentu (Wazir, 1999). Sedangkan partisipasi masyarakat adalah masyarakat terlibat ikut serta pada prosen pengindentifikasian permasalahan dan potensi yng ada pada masyarakat, memilih, serta mengambil mengenai solusi paling alternatif dalam menangani permasalahan, melaksanakan upaya memecahkan permasalahan serta terlibat dalam proses evaluasi perubahan yang terjadi (Muslimin, 2012).

Menurut Cohen dalam Naimah (2017) membedakan jenis partisipasi yakni: pertama, partisipasi dalam pengambilan keputusan, kaitannya dengan menentukan alternatif masyarakat mengenai gagasan/ide mengenai kepentingan bersama untuk memastikan orientasi dan arah pembangunan. Kedua, partisipasi dalam pelaksanaan. Partisipasi ini menyangkut bagaimana masyarakat berkontribusi dalam menjalankan suatu program seperti: kegiatan administrasi, dana, menggerakkan sumber daya, koordinasi dan menjabarkan program. Ketiga, partisipasi dalam pengambilan manfaat, menyangkut hasil dari ketercapaian program baik dari segi quality maupun quantity. Dari segi kualitas seperti peningkatan output, sedangkan segi kuantitas seperti persentase keberhasilan program. Keempat, partisipasi dalam evaluasi, menyangkut urusan pelaksanaan program secara keseluruhan, tujuannya untuk mengetahui keberhasilan program sesuai dengan perencanaan dan terhindar dari penyimpangan.

\section{Kompetensi Sumber Daya Manusia}

Menurut Hevesi (2005) kompetensi merupakan karakteristik yang dimiliki seseorang berupa pengetahuan (knowledge), kemampuan (ability), dan keterampilan (skill) dalam pelaksanaan suatu pekerjaan. Tingkatan kompetensi bisa dinilai berdasarkan latar belakang pendidikan yang dimiliki, pelatihan, serta ketrampilan yang dimiliki.

Sumber daya manusia merupakan hal yang sangat penting dalam pelaksanaan tugas dan menjalankan fungsi organisasi. Sumber daya manusia dapat mempengaruhi keberhasilan suatu pengelolaan dalam organisasi, seperti yang dikemukakan oleh Mathis (2002) yang menyebutkan bahwa nilai sumber daya manusia dipengaruhi oleh penggunaan kemampuan atau keahlian (kompetensi) yang dimiliki oleh manusia ketika melakukan suatu pekerjaan dengan semaksimal mungkin tanpa melihat latar belakang untuk mengembangkan kompetensi mereka.

\section{Pengawasan}

Pengawasan merupakan suatu aktivitas untuk mendapatkan kepastian mengenai suatu pelaksanan kegiatan atau pekerjaan apakah sudah sesuai aturan, rencana serta tujuan yang disepakati (Baswir,1997). Pemerintah melakukan pengawasan dapat meningkatkan akuntabilitas keuangan dengan mengevaluasi dan memperkaiti pengendalian internal, management risk dan proses tata kelala pemerintahan (Aikins, 2011).

Pengesahan UU Desa oleh Dewan Perwakilan Rakyat Republik Indonesia (DPR RI), menimbulkan kekhawatiran dari berbagai kalangan, hal itu dikarenakan bukan membawa keuntungan bagi pembangunan desa, melainkan akan menjadikan lahan baru untuk tindakan korupsi dan inefisiensi ditingkat desa (Sofyani, 2018). Oleh karena itu, sangat dibutuhkan pengawasan dalam mengatasi kekhawatiran tersebut. 


\section{Akuntabilitas Pengelolaan Dana Desa}

Menurut Lembaga Administrasi Negara dan Badan Pengawasan Keuangan dan Pembangunan RI (2000:12), akuntabilitas merupakan suatu kewajiban untuk mempertanggungjawabkan tindakan dan kinerja seseorang atau pimpinan pada unit organisasi kepada pihak yang berhak atau berwenang diberi pertanggungjawaban. Semakin baik suatu sistem akuntansi yang memberikan informasi yang handal, akurat, pertanggungjawaban, dan tepat waktu maka akuntabilitasnya akan semakin baik (Lestari, 2014).

Pada pemerintah desa, akuntabilitas melibatkan kemampuan pemerintah desa untuk melakukan pertanggungjawaban atas aktivitas yang dilaksanakan yang berkenaan dengan pembangunan pemerintahan desa (Sukasmanto, dalam Sumpeno, 2011).

Suatu organisasi dapat disebut memiliki manajemen yang akuntabel apabila dalam kegiatannya terpenuhi syarat: (1) penentuan tujuan yang tepat, (2) pengembangan standar sesuai kebutuhan dalam mencapai tujuan, (3) melakukan promosi penerapan pemakaian standar secara efektif, (4) pengembangan standar organisasi dan operasi secara efisien dan ekonomis (Husna, 2016).

Tingkat akuntabilitas dana desa memberi wadah kepada masyarakat untuk terlibat langsung dan aktif dalam menyelenggarakan pengawasan pembangunan, sehingga proses pembangunan berpotensi dilakukan secara transparan, akuntabel, dan partisipatif (Naimah, 2017).

\section{Kerangka Pemikiran}

\section{Pengaruh Partisipasi Masyarakat terhadap Akuntabilitas Pengelolaan Dana Desa}

Partisipasi masyarakat ialah keterlibatan masyarakat dalam proses mengindentifikasikan masalah dan potensi yang dimiliki masyarakat, dan mengambil putusan mengenai alternatif solusi untuk penanganan masalah, melaksanakan cara mengatasi masalah serta keterlibatan masyarakat dalam pengevaluasian perubahan yang terjadi (Adi, 2007:27)

Akuntabilitas akan tercapai jika adanya partisipasi dari masyarakat yang menyampaikan segala aspirasi serta berkontribusi dalam proses pengelolaan dana yang diperoleh. Berdasarkan asas pengelolaan keuangan desa yang dilakukan secara partisipatif, akuntabel, tertib, dan disiplin anggaran yang mengharuskan keterlibatan masyarakat dalam pengelolaannya.

\section{Pengaruh Kompetensi Sumber Daya Manusia Terhadap Akuntabilitas Pengelolaan Dana Desa}

Menurut Sumarsono (2003) sumber daya manusia merupakan kualitas usaha yang dilakukan oleh seseorang dalam jangka waktu yang telah ditentukan agar menghasilkan barang atau jasa. Sedangkan kompetensi merupakan kemampuan (ability) atau kapasitas seseorang untuk mengerjakan berbagai tugas dalam pekerjaannya, yang mana kemampuannya tersebut terdiri dari faktor kemampuan intelektual dan fisik (Robbin, 2007:38).

Berkaitan dengan dana desa tentu saja sumber daya manusia yang memumpuni sangat diperlukan dalam pengelolaan keuangan desa serta pertanggungjawabannya. Jika aparatur desa berkompeten dalam mengelola keuangan desa tentu saja akan meningkatkan akuntabilitas dari pengelolaan dana desa tersebut. Sebaliknya jika aparatur desa tidak memiliki sumber daya yang memadai dalam melaksanakan tugas dan fungsinya tentu saja akuntabilitas tidak akan tercapai. Oleh karena itu, kompetensi sumber daya manusia mempengaruhi akuntabilitas pengelolaan dana desa.

\section{Pengaruh Pengawasan Terhadap Akuntabilitas Pengelolaan Dana Desa}

Pengawasan merupakan proses pengamatan terhadap pelaksanaan seluruh aktivitas organisasi untuk memastikan supaya seluruh tugas yang dilaksanakan sesuai dengan perencanaan (Siagian, 2002). Tercapainya prinsip akuntabilitas dalam pengelolaan dana desa dapat diketahui melalui pengawasan mulai dari tahap perencanaan sampai dengan pertanggungjawaban. Sehingga setiap proses dalam mengelola dana desa sangat dibutuhkan pengawasan agar pengelolaan terlaksana secara efektif dan terhindar dari penyimpangan. Oleh karena itu, pengawasan mempengaruhi akuntabilitas pengelolaan dana desa.

Berdasarkan penjelasan diatas, maka skema kerangka pemikiran dapat digambarkan sebagai berikut:

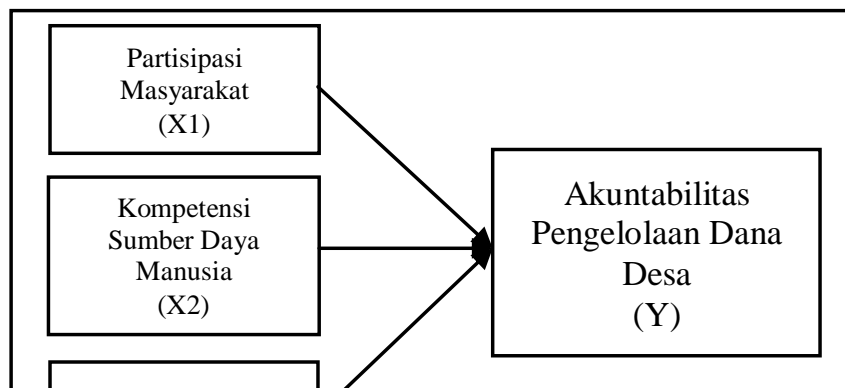




\section{Hipotesis Penelitian}

Berdasarkan teori yang telah uraikan sebelumnya, maka dapat dirumuskan beberapa hipotesis penelitian sebagai berikut:

H1: Partisipasi masyarakat (X1), Kompetensi sumber daya manusia (X2), dan Pengawasan (X3) secara bersama-sama berpengaruh positif terhadap Akuntabilitas Pengelolaan Dana Desa (Y)

H2: Partisipasi masyarakat (X1) berpengaruh positif terhadap akuntabilitas pengelolaan dana desa (Y)

H3: Kompetensi sumber daya manusia (X2) berpengaruh positif terhadap akuntabilitas pengelolaan dana desa (Y)

H3: Pengawasan (X3) berpengaruh positif terhadap akuntabilitas pengelolaan dana desa (Y)

\section{Metode Penelitian}

\section{Desain Penelitian}

Penelitian ini menggunakan pengujian hipotesis yang dirumuskan berdasarkan teori dan literatur terdahulu. Jenis investigasi dari penelitian ini bersifat studi kausalitas. Penelitian ini menggunakan data primer berupa kuesioner. Horizon waktu yang digunakan dalam penelitian ini adalah cross sectional. Tingkat intervensi penelitian ini ialah intervensi minimal.

\section{Populasi Sampel}

Populasi dalam penelitian ini adalah seluruh desa yang ada di kabupaten Aceh Barat Daya yang berjumlah 152 desa. Sampel dipilih metode simple random sampling dengan perhitungan rumus slovin. Sampel penelitian berjumlah 60 desa. kuesioner didistribusikan pada 2 orang setiap desa yang terdiri dari tuha peut gampong dan tokoh masyarakat sehingga jumlah responden sebanyak 120 orang.

\section{Teknik Pengumpulan Data}

Pengumpulan data primer melalui pendistribusian kuesioner kepada responden yang terdiri dari tuha peut gampong dan tokoh masyarakat yang ada di kabupaten Aceh Barat Daya.

\section{Metode Analisis Data}

Alat analisis yang digunakan dalam penelitian ini adalah analisis regresi linear berganda untuk pengujian hipotesis. Model regresi penelitian ini ialah sebagai berikut:

$$
\mathrm{Y}=\mathrm{a}+\mathrm{b} 1 \mathrm{X} 1+\mathrm{b} 2 \mathrm{X} 2+\mathrm{b} 3 \mathrm{X} 3+\mathrm{e}
$$

Keterangan:

$\mathrm{Y}=$ Akuntabilitas pengelolaan Dana Desa

$\mathrm{a}=$ Konstanta

b1, b2, b3 = Koefisien regresi X1, X2, dan X3

$\mathrm{X} 1=$ partisipasi masyarakat

$\mathrm{X} 2$ = kompetensi sumber daya manusia

$\mathrm{X} 3$ = Pengawasan

$\mathrm{e}=$ Error

Pengelolaan data dilakukan menggunakan program SPSS versi 21, dengan tingkat signifikansi 5\%.

\section{Hasil dan Pembahasan \\ Deskripsi dan Analisis Data}

Penelitian ini dilakukan dengan mendistribusikan kuesioner kepada responden yang terdiri dari dari tuha peut gampong dan tokoh masyarakat di Kabupaten Aceh Barat Daya. Keseluruhan responden berjumlah 120 orang dengan tingkat pengembalian kuesioner sebesar $80 \%$ atau 97 kuesioner yang terdiri dari 51 orang tuha peut dan 46 orang tokoh masyarakat.

\section{Uji Kualitas Data}

\section{Hasil Uji Validitas}

Pengujian kualitas data dilakukan secara statistik uji pearson product-moment coefficient of corelations dengan nilai signifikansi sebesar 5\%. Masing-masing item disebut valid jika nilai $r$ hitung $>r$ tabel. Hasil uji validitas dapat dilihat pada Tabel 4.1 berikut:

Tabel 4.1

Hasil pengujian validitas

\begin{tabular}{|l|l|l|l|l|l|}
\hline No & Item & Variabel & Koefisien Korelasi $\left(\mathbf{R}_{\text {Hitung }}\right)$ & Nilai Kritis \% ( $\left.\mathbf{R}_{\text {Tabel }}\right)$ & Ket
\end{tabular}




\begin{tabular}{|c|c|c|c|c|c|}
\hline 1 & PM1 & \multirow{6}{*}{$\begin{array}{l}\text { Partisipasi Masyarakat } \\
\text { (X1) }\end{array}$} & 0,667 & \multirow{6}{*}{0,1996} & \multirow{6}{*}{ Valid } \\
\hline 2 & PM2 & & 0,620 & & \\
\hline 3 & PM3 & & 0,740 & & \\
\hline 4 & PM4 & & 0,648 & & \\
\hline 5 & PM5 & & 0,712 & & \\
\hline 6 & PM6 & & 0,675 & & \\
\hline 7 & KSDM1 & \multirow{6}{*}{$\begin{array}{l}\text { Kompetensi Sumber Daya } \\
\text { Manusia (X2 }\end{array}$} & 0,530 & \multirow{6}{*}{0,1996} & \multirow{6}{*}{ Valid } \\
\hline 8 & KSDM2 & & 0,648 & & \\
\hline 9 & KSDM3 & & 0,683 & & \\
\hline 10 & KSDM4 & & 0,594 & & \\
\hline 11 & KSDM5 & & 0,573 & & \\
\hline 12 & KSDM6 & & 0,646 & & \\
\hline 13 & $\mathrm{P} 1$ & \multirow{6}{*}{ Pengawasan (X3) } & 0,761 & \multirow{6}{*}{0,1996} & \multirow{6}{*}{ Valid } \\
\hline 14 & $\mathrm{P} 2$ & & 0,719 & & \\
\hline 15 & P3 & & 0,548 & & \\
\hline 16 & $\mathrm{P} 4$ & & 0,848 & & \\
\hline 17 & P5 & & 0,768 & & \\
\hline 18 & P6 & & 0,588 & & \\
\hline 19 & APDG1 & \multirow{8}{*}{$\begin{array}{l}\text { Akuntabilitas Pengelolaan } \\
\text { Dana Gampong (Y) }\end{array}$} & 0,763 & \multirow{8}{*}{0,1996} & \multirow{8}{*}{ Valid } \\
\hline 20 & APDG2 & & 0,723 & & \\
\hline 21 & APDG3 & & 0,702 & & \\
\hline 22 & APDG4 & & 0,647 & & \\
\hline 23 & APDG5 & & 0,707 & & \\
\hline 25 & APDG6 & & 0,767 & & \\
\hline 26 & APDG7 & & 0,820 & & \\
\hline 27 & APDG8 & & 0,751 & & \\
\hline
\end{tabular}

Berdasarkan uji validitas diatas, masing-masing item memperoleh nilai $r_{\text {hitung }}>r_{\text {tabel }}$, yang berarti bahwa seluruh instrumen kuesioner adalah valid.
Pengujian reliabilitas dilakukan agar item kuesioner dapat mencapai tingkat validitas dengan tujuan untuk menunjukkan keakuratan dari kuesioner yang digunakan. Berikut hasil uji reliabilitas :

\section{Hasil Uji Reliabilitas}

Tabel 4.2

Hasil Pengujian Reliabilitas

\begin{tabular}{|l|c|c|c|}
\hline Variabel & Crombach Alpha & Nilai Kritis Crombach's Alpha & Keterangan \\
\hline $\begin{array}{l}\text { Partisipasi Masyarakat } \\
(\mathrm{X} 1)\end{array}$ & 0,764 & 0,60 & Reliabel \\
\hline $\begin{array}{l}\text { Kompetensi Sumber Daya Manusia } \\
(\mathrm{X} 2)\end{array}$ & 0,667 & 0,60 & Reliabel \\
\hline $\begin{array}{l}\text { Pengawasan } \\
(\mathrm{X} 3)\end{array}$ & 0,796 & 0,60 & Reliabel \\
\hline $\begin{array}{l}\text { Akuntabilitas Pengelolaan Dana Gampong } \\
(Y)\end{array}$ & 0,879 & 0,60 & Reliabel \\
\hline
\end{tabular}

Berdasarkan Tabel 4.2 di atas, uji reliabilitas menghasilkan nilai Cronbach Alpha lebih besar dari 0,60 untuk setiap variabel. Hal ini menunjukkan bahwa kuesioner yang digunakan memiliki reliabilitas yang sangat baik. 


\section{Hasil Uji Asumsi Klasik Uji Normalitas}

Tabel 4.3

Uji Normalitas

\begin{tabular}{|l|l|l|}
\hline & $\begin{array}{l}\text { Unstandardiz } \\
\text { Ed Residual }\end{array}$ & Keterangan \\
\hline $\begin{array}{l}\text { Asymp. Sig. } \\
\text { (2-tailed) }\end{array}$ & 0.970 & $\begin{array}{l}\text { Data berdistribusi } \\
\text { normal }\end{array}$ \\
\hline
\end{tabular}

Berdasarkan tabel 4.3 menunjukkan bahwa nilai signifikansi (Asymp.Sig 2-tailed) sebesar 0,970. Hal ini berarti nilai residual telah terdistribusi secara normal, karena nilai signifikansi lebih dari 0,05 $(0,970>0,05)$.

\section{Uji Multikolinearitas}

Tabel 4.4

Uji Multikolonieritas

Nilai Variance Inflation Factor (VIF) Variabel

\begin{tabular}{|c|c|c|c|}
\hline \multirow[b]{2}{*}{ Model } & \multicolumn{2}{|c|}{ Collinearity Statistics } & \multirow{2}{*}{ Kesimpulan } \\
\hline & Tolerance & VIF & \\
\hline \multirow{4}{*}{$1 \mathrm{PM}$} & .889 & 1.125 & \\
\hline & .961 & 1.040 & 1 Iun \\
\hline & .862 & 1.159 & tas \\
\hline & & & \\
\hline
\end{tabular}

Berdasarkan tabel 4.4, dapat disimpulkan bahwa tidak terjadi gejala multikolinearitas. Nilai tolerance untuk setiap variabel bebas berada di atas 0,10 dan nilai VIF (Variance Inflation Factor) variabel bebas tidak ada yang diatas 10 , hal ini berarti tidak adanya multikolinieritas.

\section{Uji Heterokedastisitas}

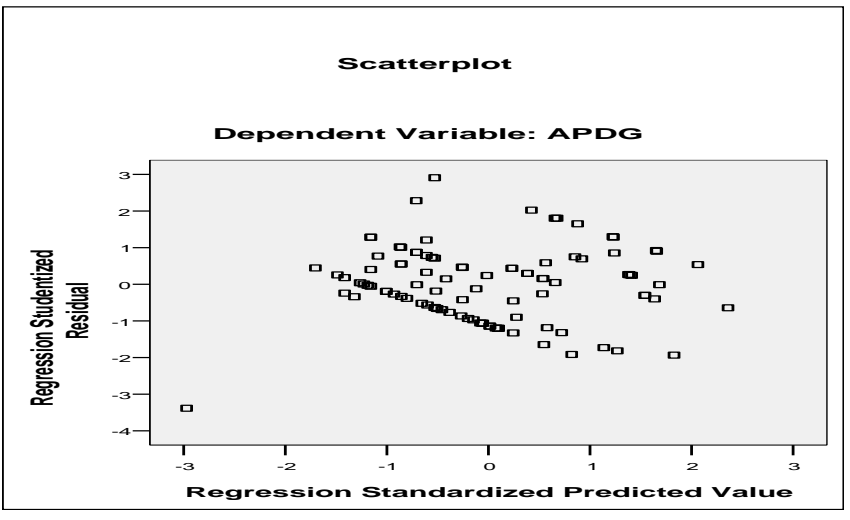

Gambar 4.1 Hasil Uji Heteroskedastisitas dengan Grafik Scatterplot

Berdasarkan hasil pengujian diatas, menunjukkan bahwa titik-titik menyebar secara acak baik di atas maupun di bawah sumbu Y sehingga pola titik-titiknya tidak teratur. Dapat disimpulkan bahwa variabel bebas tidak terdapat heterokedastisitas pada model regresi.

\section{Hasil Analisis Regresi Linear Berganda}

Model penelitian dapat dilihat pada hasil pengolahan data seperti yang terlihat pada bagian output SPSS di Tabel 4.5 dibawah ini:

Tabel 4.5

Pengaruh Variabel Independen terhadap Variabel Dependen

\begin{tabular}{|c|c|c|c|c|c|}
\hline \multirow[b]{2}{*}{ Model } & \multicolumn{2}{|c|}{$\begin{array}{l}\text { Unstandardized } \\
\text { Coefficients }\end{array}$} & \multirow{2}{*}{$\begin{array}{l}\text { Standardized } \\
\text { Coefficients } \\
\text { Beta }\end{array}$} & \multirow[b]{2}{*}{$\mathrm{t}$} & \multirow[b]{2}{*}{ Sig. } \\
\hline & B & $\begin{array}{l}\text { Std. } \\
\text { Error }\end{array}$ & & & \\
\hline 1 (Constant) & -.274 & .527 & & -.519 & .605 \\
\hline PM & .233 & .085 & .221 & 2.729 & .008 \\
\hline KSDM & .418 & .088 & .369 & 4.732 & .000 \\
\hline $\mathrm{P}$ & .439 & .095 & .380 & 4.615 & .000 \\
\hline
\end{tabular}

Berdasarkan hasil uotput SPSS (coeficients), dapat diperoleh persanaan regfesi berganda (multipple regresion) yaitu:

$$
\mathrm{Y}=-\mathbf{0 . 2 7 4}+0.233 \mathrm{X} 1+0.418 \mathrm{X} 2+0.439 \mathrm{X} 3+e
$$

Nilai konstan sebesar -0,274 menunjukkan bahwa jika partisipasi masyarakat, kompetensi sumber daya mansuia, dan pengawasan dianggap bernilai 0 , maka tingkat akuntabilitas pengelolaan dana desa sebesar $-0,274$ atau 2,74\%. Dengan kata lain, tingkat 
akuntabilitas pengelolaan dana desa sebesar $-0,274$ tidak dipengaruhi oleh variabel-variabel independen.

\section{Hasil Uji Koefisien Korelasi $\left(\mathbf{R}^{2}\right)$}

Tabel 4.6

\section{Koefisien Korelasi}

\begin{tabular}{|l|l|l|l|l|}
\hline Model & R & R Square & $\begin{array}{l}\text { Adjusted } \\
\text { R Square }\end{array}$ & $\begin{array}{l}\text { Std. Error of } \\
\text { the Estimate }\end{array}$ \\
\hline 1 & $.675^{\mathrm{a}}$ & .456 & .438 & .28799 \\
\hline
\end{tabular}

Koefisien korelasi (R) sebesar 0.675 menunjukkan bahwa derajat korelasi (hubungan) antara variabel independen dan variabel dependen sebesar $67,5 \%$. Hal ini berarti akuntabilitas pengelolaan dana gampong kabupaten aceh barat daya terdapat hubungan dengan faktor-faktor partisipasi masyarakat (X1), kompetensi sumber daya manusia (X2), dan pengawasan (X3). Selanjutnya, koefisien determinasi $\left(\mathrm{R}^{2}\right)$ sebesar 0.456 , hal ini berarti perubahan akuntabilitas pengelolaan dana desa sebesar 45.6\% dipengaruhi oleh faktor partisipasi masyarakat (X1), kompetensi sumber daya manusia (X2), dan pengawasan (X3), sedangkan sisanya dipengaruhi oleh variabel-variabel lain yang tidak digunakan pada penelitian ini.

\section{Hasil Pengujian Hipotesis Hasil Uji Secara Simultan}

Tabel 4.7

Hasil Uji F

ANOVA $^{b}$

\begin{tabular}{|c|c|c|c|c|c|}
\hline Model & $\begin{array}{l}\text { Sum of } \\
\text { Square }\end{array}$ & df & $\begin{array}{l}\text { Mean } \\
\text { Square }\end{array}$ & $\mathrm{F}$ & Sig. \\
\hline 1 Regression & 6.461 & $\overline{3}$ & 2.154 & 25.968 & $.000^{\mathrm{a}}$ \\
\hline Residual & 7.713 & 93 & .083 & & \\
\hline Total & 14.175 & 96 & & & \\
\hline
\end{tabular}

Berdasarkan tabel 4.7 dapat dilihat dari nilai Fhitung sebesar 25,968 sedangkan nilai F-tabel sebesar 2,703. Hal ini menunjukkan bahwa F-hitung > F-tabel, maka dapat disimpulkan bahwa hipotesis alternatif (Ha1) diterima. Oleh karena itu secara simultan variabel partisipasi masyarakat (X1), kompetensi sumber daya manusia (X2), dan pengawasan (X3) secara signifikan berpengaruh terhadap akuntabilitas pengelolaan dana desa $(\mathrm{Y})$.

\section{Hasil Uji Secara Parsial}

Tabel 4.8

Hasil Uji Parsial (T)

\begin{tabular}{|c|c|c|c|c|c|}
\hline \multirow[b]{2}{*}{ Model } & \multicolumn{2}{|c|}{$\begin{array}{l}\text { Unstandardized } \\
\text { Coefficients }\end{array}$} & \multirow{2}{*}{$\begin{array}{c}\text { Standardized } \\
\text { Coefficients }\end{array}$} & \multirow[b]{2}{*}{ t } & \multirow[b]{2}{*}{ Sig. } \\
\hline & B & $\begin{array}{l}\text { Std. } \\
\text { Error }\end{array}$ & & & \\
\hline (Constant) & -.274 & .527 & & -.519 & .605 \\
\hline PM & .233 & .085 & .221 & 2.729 & .008 \\
\hline KSDM & .418 & .088 & .369 & 4.732 & .000 \\
\hline $\mathrm{P}$ & .439 & .095 & .380 & 4.615 & .000 \\
\hline
\end{tabular}

Pengujian secara parsial pengaruh partisipasi masyarakat, kompetensi sumber daya manusia dan pengawasan dapat peroleh dengan cara melhat dari nilai signifikansi masing-masing variabel. Setiap variabel dikatakan berpengaruh, apabila nilai signifikansi nya lebih kecil dari 0,05 . Berikut hasil perhitungan nilai signifikansi masing-masing varibel.

1. Variabel partisipasi masyarakat memiliki nilai $\mathrm{t}$ hitung sebesar 2.729, sedangkan nilai t-tabel adalah 1,986. Hal ini berarti dengan tingkat signifikan 5\% maka hipotesis dapat diterima. Oleh karena itu, karena t-hitung 2,729 > t-tabel 1,986. Hal ini berarti koefisien partisipasi masyarakat mempunyai pengaruh terhadap akuntabilitas pengelolaan dana desa.

2. Variabel kompetensi sumber daya manusia memiliki nilai $\mathrm{t}$ - hitung adalah sebesar 4,732, sedangkan nilai t-tabel adalah 1,986. Hal ini berarti, jika t-hitung $>\mathrm{t}$ - tabel dengan tingkat signifikan $5 \%$ maka hipotesis dapat diterima. Oleh karena itu, karena t-hitung 4,732 > t-tabel 1,986. Hal ini berarti koefisien kompetensi sumber daya manusia mempunyai pengaruh terhadap akumtabilitas pengelolaan dana desa.

3. Variabel pengawasan memiliki nilai t-hitung adalah sebesar 4,615, sedangkan nilai t-tabel adalah 1,986. Hal ini berarti, jika t-hitung $>$ t-tabel dengan tingkat signifikan 5\% maka hipotesis dapat diterima karena t-hitung 4,615 > t-tabel 1,986. Hal ini berarti koefisien pengawasan mempunyai pengaruh terhadap akuntabilitas pengelolaan dana desa.

\section{Pembahasan}

Pengaruh Partisipasi Masyarakat terhadap Akuntabilitas Pengelolaan Dana Desa 
Hasil pengujian regresi linear terlihat nilai koefisien regresi menunjukkan bahwa partisipasi masyarakat berpengaruh terhadap akuntabilitas pengelolaan dana desa. Hal ini menunjukkan bahwa rancangan hipotesis diterima, yaitu partisipasi masyarakat berpengaruh terhadap akuntabilitas pengelolaan dana desa. Oleh karena itu semakin meningkat partisipasi masyarakat dalam hal keuangan desa, maka akan meningkatkan akuntabilitas pengelolaan dana desa. Hasil penelitian ini sejalan dengan penelitian yang telah dilakukan sebelumnya dan dijadikan referensi dalam penelitian ini. Penelitian yang sesuai tersebut seperti penelitian yang dilakukan oleh Medianti (2018), menyatakan bahwa terdapat pengaruh dari partisipasi terhadap akuntabilitas dana desa, hal ini dibuktikan dengan semakin meningkat partisipasi masyarakat, maka semakin tinggi jumlah individu yang terlibat dalam pengambilan keputusan dan pelaksanaan kegiatan yang menyangkut dengan kebutuhan masyarakat. Semakin tinggi keterlibatan individu tersebut maka semakin tinggi pula rasa tanggungjawab mereka untuk melaksanakan keputusan yang telah dihasilkan, dan pembangunan akan menjadi semakin baik kedepannya, pembangunan suatu desa dikatakan baik apabila hasil dari pengelolaan dana desa yang baik pula. Artinya semakin intens partisipasi masyarakat, maka pengelolaan dana desa semakin akuntabel.

\section{Pengaruh Kompetensi Sumber Daya Manusia terhadap Akuntabilitas Pengelolaan Dana Desa}

Hasil pengujian regresi linear terlihat nilai koefisien regresi menunjukkan bahwa kompetensi sumber daya manusia berpengaruh terhadap akuntabilitas pengelolaan dana desa. Hal ini menunjukkan bahwa rancangan hipotesis diterima, yaitu kompetensi sumber daya manusia berpengaruh terhadap akuntabilitas pengelolaan dana desa. Jika aparatur desa memiliki keahlian dan pengetahuan dalam mengelola keuangan desa, maka proses pengelolaan keuangan desa akan mencapai akuntabilitas. Oleh karena itu semakin baik kompetensi sumber daya manusia dalam hal pengelolaan keuangan desa, maka akan meningkatkan akuntabilitas pengelolaan dana desa.

Hasil penelitian ini sejalan dengan penelitian yang telah dilakukan sebelumnya dan dijadikan referensi dalam penelitian ini. Penelitian yang sesuai tersebut seperti penelitian yang dilakukan oleh Ismail, dkk (2016) yang menyatakan bahwa kompetensi sumber daya manusia sangat berpengaruh terhadap pengelolaan dana desa. Penelitian ini juga sejalan dengan penelitian ini seperti yang dilakukan oleh Mada (2017), yang menunjukkan hasil bahwa kompetensi sumber daya manusia dari aparatur desa berdampak positif terhadap akuntabilitas tata kelola dana desa.

\section{Pengaruh Pengawasan terhadap Akuntabilitas Pengelolaan Dana Desa}

Hasil pengujian regresi linear terlihat nilai koefisien regresi menunjukkan bahwa pengawasan berpengaruh terhadap akuntabilitas pengelolaan dana desa. Hal ini menunjukkan bahwa rancangan hipotesis diterima, yaitu pengawasan berpengaruh terhadap akuntabilitas pengelolaan dana desa. Dengan adanya pengawasan maka pengelolaan keuangan akan terhindar dari penyimpangan dan tetap berjalan sesuai dengan aturan dan tujuan yang ditetapkan. Pengawasan dilakukan oleh tuha peut dan masyarakat sebagai pihak internal dan inspektorat kabupaten sebagai pihak eksternal, dengan adanya pengawasan yang ketat dan berkala maka aparatur desa akan melakukan pengelolaan keuangan sesuai dengan aturan dan prosedur sehingga meminimalisir terjadinya kecurangan atau penyimpangan dalam pengelolaan keuangan desa. Oleh karena itu semakin meningkat pengawasan dalam hal keuangan desa, maka akan meningkatkan akuntabilitas pengelolaan dana desa.

Hasil penelitian ini sejalan dengan penelitian yang telah dilakukan sebelumnya dan dijadikan referensi dalam penelitian ini. Seperti yang dilakukan oleh Munti (2017), yang menyatakan bahwa kualitas pengawasan berpengaruh terhadap kinerja pengelolaan keuangan desa. Hal ini menunjukkan bahwa semakin meningkatnya pengawasan terhadap pengelolaan keuangan desa, maka akan semakin meningkatkan kinerja pengelolaan keuangan desa.

\section{Kesimpulan, Keterbatasan Dan Saran Kesimpulan}

Berdasarkan hasil pengujian hipotesis maka diperoleh kesimpulan sebagai berikut:

1. Partisipasi masyarakat, kompetensi sumber daya manusia, dan pengawasan berpengaruh secara 
bersama-sama terhadap akuntabilitas pengelolaan dana desa.

2. Partisipasi masyarakat berpengaruh positif terhadap akuntabilitas pengelolaan dana desa.

3. Kompetensi sumber daya manusia berpengaruh positif terhadap akuntabilitas pengelolaan dana desa.

4. Pengawasan berpengaruh positif terhadap akuntabilitas pengelolaan dana desa.

\section{Keterbatasan Penelitian}

Adapun keterbatasan yang terdapat pada penelitian ini yaitu sebagai berikut.

1. Penelitian ini menggunakan teknik pengumpulan data berupa kuesioner dan data diperoleh berdasarkan persepsi responden berupa jawaban yang terdapat kemungkinan bahwa hasil jawaban akan berbeda dengan keadaan sebenarnya.

2. Penelitian ini hanya menggunakan tiga variabel independen saja, yakni partisipasi masyarakat, kompetensi sumber daya manusia, dan pengawasan, hal ini memungkinkan terabaikannya keadaan lain yang dapat dijadikan variabel yang dapat mempengaruhi akuntabilitas pengelolaan dana desa yang tidak dapat diikutsertakan dalam penelitian ini.

3. Penelitian ini hanya dilakukan dalam lingkup kabupaten Aceh Barat Daya, sehinggal hasil dari penelitian ini tidak dapat digeneralisasi untuk kabupaten/kota lainnya.

\section{Saran}

Adapun saran yang dapat diberikan penulis yang berkaitan dengan penelitian ini sebagai berikut.

1. Diharapkan untuk penelitian selanjutnya dalam memperoleh informasi data penelitian dapat melakukan wawacara secara langsung dan jelas dengan responden agar memperoleh hasil yang lebih detail.

2. Diharapkan untuk penelitian selanjutnya dapat memperluas objek penelitian seperti melakukan penelitian perbandingan antar kabupaten/kota lainnya.

3. Diharapkan untuk penelitian selanjutnya agar menambah variabel independen lain yang dapat mempengaruhi akuntabilitas pengelolaan dana desa.

\section{Daftar Pustaka}

Adi, Isbandi Rukminto. (2007). Perencanaan partisipatoris berbasis asset komunitas: dari pemikiran menuju penerapan. Depok: FISIP UI Press.

Aikins, Stephen K. (2011). An Examination of Government Internal Audit's Role in Improving Financial Performance. Journal of Public Finance and Management, 11 (4): 306-337.

Aucoin, Peter dan Heintzman, Ralph. (2000). The Dialectics of Accountability for Performance in Public Management Reform. International Review of Administrative Sciences. Vol. 66 : 4555

Baswir, Revrisond. (1997). Akuntansi Pemerintahan Indonesia. BPFE: Yogyakarta

Hevesi, G. Alan. (2005). Standards for Internal Control in New York State Government.

Husna, Saifatul dan Abdullah, Syukriy. (2016). Kesiapan Aparatur Desa Dalam Pelaksanaan Pengelolaan Keuangan Desa Secara Akuntabilitas Sesuai Undang-Undang Nomor 6 Tahun (2014) Tentang Desa (Studi pada Beberapa Desa di Kabupaten Pidie). Jurnal Ilmiah Mahasiswa Ekonomi Akuntansi (JIMEKA). Vol. 1, 282-293

Husin, Dasmi. (2017). Kendali Dana Desa. Serambi Indonesia. 9 Agustus. http://aceh.tribunnews.com/(2017)/08/09/kendal i-dana-desa

Ismail, M., Widagdo, A, K., \& Widodo, A. (2016). Sistem Akuntansi Pengelolaan Dana Desa. Jurnal Ekonomi dan Bisnis. Vol.19(2).

Kurnia, Dadang. (2015). Belum Melek Akuntansi, Aparatur Bakal Kesulitan Kelola Dana Desa. Berita Satu.

https://www.beritasatu.com/nasional/244773/bel um-melek-akuntansi-aparatur-bakal-kesulitankelola-dana-desa

Kholmi, (2016). Akuntabilitas Pengelolaan Alokasi Dana Desa: Studi Di Desa Kedungbetik Kecamatan Kesamben Kabupaten Jombang. Ekonomika-Bisnis. Vol. 7 No. 2

Lestari, Ayu Komang D, dkk. (2014). Membedah Akuntabilitas Praktik Pengelolaan Keuangan Desa Pakraman Kututambahan Kecamatan Buleleng Provinsi Bali (Sebuah Studi Interpretif Pada Organisasi Publik Non Pemerintah). E- 
jurnal Universitas Pendidikan Ganesha Jurusan Akuntansi Program S1. Volume 2. Nomor 1.

Mada, S., Kalangi, L., \& Gamaliel, H. (2017). Pengaruh Kompetensi Aparat Pengelola Dana Desa, Komitmen Organisasi Pemerintah Desa, dan Partisipasi Masyarakat Terhadap Akuntabilitas Pengelolaan Dana Desa Di Kabupaten Gorontalo, (Jurnal Riset Akuntansi dan Auditing, ,8(2), 106-11

Munti, Finta dan Fahlevi, Heru. (2017).Determinan Kinerja Pengelolaan Keuangan Desa: Studi pada Kecamatan Gandapura Kabupaten Bireuen Aceh.Jurnal of accounting and investment. Vol. 18 No. 2, Hlm: 172-182

Muslimin, Mappamiring, dan St. Nurmaeta. (2012). Akuntabilitas Pengelolaan Alokasi Dana Desa Di Desa Punagaya Kecamatan Bangkala Kabupaten Jeneponto. Otoritas jurnal ilmu pemerintahan. Vol II.

Mathis Robert, dan Jackson, John. (2002). Manajemen Sumber Daya Manusia. Jakarta : Salemba empat Medianti, Larastika. (2018). Pengaruh Kompetensi Aparatur, Komitmen Organisasi, Dan Partisipasi Masyarakat Terhadap Pengelolaan Dana Desa (Studi Empiris Pada Desa-Desa Di Kabupaten Bintan). JOM FEB. Vol 1

Nadir. (2013). Otonomi Daerah Dan Desentralisasi Desa: Menuju Pemberdayaan Masyarakat Desa. Jurnal Politik Profetik. Vol.1 No.1

Naimah. (2017). Faktor-Faktor Yang Mempengaruhi Akuntabilitas Keuangan Desa Pada Pemerintah Kabupaten Serdang Bedagai. Tesis Dipublikasikan. Sumatera Utara: Program Studi Magister Akuntansi Universitas Sumatera Utara

Provinsi Aceh Dalam Angka. (2018). Badan Pusat Statistik Provinsi Aceh

Republik Indonesia, Undang-Undang No. 23 tahun 2014 tentang Pemerintahan Daerah Undang-Undang Republik Indonesia, No. 6 Tahun 2014 tentang Desa

Pramesti, dan Ayu, Firdha. (2015). Akuntabilitas Pemerintah Desa Dalam Pengelolaan Alokasi Dana Desa Di Desa Temulus Kecamatan Mejobo Kabupaten Kudus. Departemen Politik Dan Pemerintahan Fakultas Ilmu Sosial Dan Ilmu Politik, Universitas Diponegoro.

Robbins, Stephen P.(2007). Perilaku Organisasi. Indonesia: PT Macanan Jaya.
Setyoko, dan Israwan, Paulus. (2011). Akuntabilitas Administrasi Keuangan Program Alokasi Dana Desa (ADD). JIANA (Jurnal Ilmu Administrasi Negara). Vol.11 No.1

Sumpeno, Wahjudin. (2011). Perencanaan Desa Terpadu. Edisi 2. Banda Aceh: Read.

Sofyani, Hafiez. (2018). Praktik Pengelolaan dan Tata Kelola Pemerintahan Desa Dlingo di Kabupaten Bantul: Pembelajaran dari Desa Percontohan. Jurnal Akuntansi Terapan Indonesia. Vol.1, No.1.

Siagian, Sondang P. (2002). Fungsi-Fungsi Manajerial. Jakarta: Rineka Cipta.

Sumarsono, Sonny.(2003). Ekonomi Manajemen Sumber Daya Manusia dan Ketenagakerjaan. Yogyakarta : Graha Ilmu. 